\title{
HIP-SPINE SYNDROME, RADIOGRAPHIC EVALUATION OF THE SAGITTAL BALANCE
}

\author{
SÍNDROME QUADRIL-COLUNA, AVALIAÇÃO RADIOGRÁFICA NO BALANÇO SAGITAL \\ SÍNDROME DE COLUMNA-CADERA, EVALUACIÓN RADIOGRÁFICA EN EL BALANCE SAGITAL
} Omar Mohamad Mansour Abdallah, ${ }^{1,2}$ Xavier Soler Graells, ${ }^{1,2}$ Álynson larocca KulCheskl, ${ }^{1}$ Pedro Grein Del Santoro, ${ }^{1}$ Marcel luis Benato, ${ }^{1}$ André Luis Sebben ${ }^{1}$

1. Universidade Federal do Paraná, Hospital de Clínicas, Department of Surgery, Curitiba, PR, Brazil.

2. Hospital do Trabalhador, Curitiba, PR, Brazil.

\begin{abstract}
Objectives: The hip-spine syndrome (HSS) is defined as the simultaneous degeneration of the hip and lumbar spine. The objective of this study is to quantify the sagittal balance values in the population with HSS and to compare them with the normal sagittal balance parameters. Methods: A retrospective study was conducted in which 30 patients with HSS who were waiting for total hip arthroplasty (THA) were evaluated. The lumbar lordosis (LL), sacral slope (SS), pelvic tilt (PT), pelvic incidence $(\mathrm{Pl})$ and spinopelvic harmony $(\mathrm{SH})$ angles and the BMI of these patients were measured. Results: Seventeen women and 13 men participated in the study, with a mean LL of $39.55^{\circ}$, a mean SS of $36.92^{\circ}$, a mean PT of $25.77^{\circ}$, a mean $\mathrm{PI}$ of $62.72^{\circ}$, a mean $\mathrm{SH}$ of $23.17^{\circ}$ and a mean BMI of 25.55. Only the SS did not present a changed value when compared to the normal values of the population. Conclusions: HSS is increasingly present in our environment due to the aging population. Sagittal balance is gaining more and more attention in studies related to spinal pathologies. All the parameters measured in this study, except for SS, presented altered values when compared to the populational means. Evidence Level II. Observational and retrospective study.
\end{abstract}

Keywords: Postural Balance; Osteoarthritis, Spine; Arthroplasty, Replacement, Hip; Low back Pain; Pelvis; Radiography.

\section{RESUMO}

Objetivos: A síndrome quadril-coluna (SQC) é definida como a degeneração simultânea do quadril e da coluna lombar. O objetivo do presente estudo consiste em quantificar os valores do equilíbrio sagital na população com SQC e compará-los com os parâmetros normais do equilíbrio sagital. Métodos: Foi realizado um estudo retrospectivo em que foram avaliados 30 pacientes com SQC aguardando cirurgia de artroplastia total de quadril (ATQ). Foram aferidos os ângulos de lordose lombar (LL), declive sacral (DS), versão pélvica (VP), incidência pélvica (IP), harmonia espinopélvica (HP) e o IMC dos pacientes no estudo. Resultados: Participaram do estudo 17 mulheres e 13 homens, sendo que a LL média foi de $39,55^{\circ}, D S 36,92^{\circ}, V P 25,77^{\circ}, I P$ 62,72 ${ }^{\circ}, H P 23,17^{\circ}$ e IMC 25,55. Apenas o DS não apresentou valor alterado quando comparado aos valores normais da população. Conclusão: A SQC está cada vez mais presente em nosso meio devido ao envelhecimento populacional. O equilíbrio sagital ganha cada vez mais espaço nos estudos relacionados às patologias da coluna vertebral. Com exceção do DS, os demais parâmetros medidos nesse estudo apresentaram valores alterados quando comparados à média populacional. Nível de Evidência II. Estudo observacional e retrospectivo.

Descritores: Equilíbrio Postural; Osteoartrite da Coluna Vertebral; Artroplastia de Quadril; Osteoartrite do Quadril; Dor Lombar; Pelve; Radiografia.

\section{RESUMEN}

Objetivos: El Síndrome de Columna-Cadera (SCC) se define como la degeneración simultánea de la columna lumbar y la cadera. El objetivo del presente estudio consiste en cuantificar los valores del equilibrio sagital en la población con SCC y compararlos con los parámetros normales del equilibrio sagital. Métodos: Se realizó un estudio retrospectivo en el que se evaluaron 30 pacientes con SCC que esperaban cirugía para artroplastia total de cadera (ATC). Fueron medidos los ángulos de lordosis lumbar (LL), pendiente sacra (PS), versión pélvica (VP), incidencia pélvica (IP), armonía espinopélvica (AP) y el IMC de los pacientes en el estudio. Resultados: Participaron en el estudio 17 mujeres y 13 hombres, siendo que la $L L$ promedio fue de $39,55^{\circ}, P S 36,92^{\circ}, V P 25,77^{\circ}, I P 62,72^{\circ}, A P$ 23, $17^{\circ}$ e IMC 25,55. Sólo la PS no presentó un valor alterado, cuando comparado a los valores normales de la población. Conclusión: EI SCC está cada vez más presente en nuestro medio debido al envejecimiento poblacional. El equilibrio sagital está ganando cada vez más espacio en los estudios relacionados a las patologías de la columna vertebral. Con excepción de la PS, los demás parámetros medidos en este estudio presentaron valores alterados cuando comparados al promedio poblacional. Nivel de Evidencia II. Estudio observacional y retrospectivo.

Descriptores: Equilibrio Postural; Osteoartritis de la Columna Vertebral; Artroplastia de Reemplazo de Cadera; Osteoartritis de la Cadera; Dolor de la Región Lumbar; Pelvis; Radiografía. 


\section{INTRODUCTION}

Hip-spine syndrome (HSS) is defined as the occurrence of simultaneous degenerative alterations in the hip and lumbar spine. The lumbopelvic complex and the hip joints are anatomical structures that interact. ${ }^{1}$ The loss of harmony of the lumbopelvic complex leads to overloads on the joints of both the hips and the lumbosacral spine and to the overall incapacitation of apparatus., ${ }^{2,3}$

The spine and the pelvis have an intimate relationship that we call sagittal balance. Duval Beaupèrre described radiographic parameters for measuring this balance: pelvic incidence $(\mathrm{PI})$, pelvic tilt (PT) and sacral slope (SS). ${ }^{4,5}$ These last two parameters can vary according to the position of the pelvis in the space and have their values changed as a compensation mechanism secondary to spinal pathologies. ${ }^{6} \mathrm{PI}$, on the other hand, has fixed values. Changes related to osteoarticular, myofascial structures or in the spinopelvic parameters can trigger sagittal imbalance. (Figure 1)

In addition to the parameters reported by Duval Beaupèrre, spinopelvic harmony is also described as the relationship between pelvic incidence (PI) and lumbar lordosis (LL), calculated by subtracting $\mathrm{LL}$ from $\mathrm{PI}$, and ranging from $10-20^{\circ}$. This parameter has been strongly correlated with pain and functional disability when outside the normal range of values. ${ }^{8}$

The literature has shown that spine pathologies can alter the spinopelvic sagittal balance and there is also evidence that restoration of the biomechanics of the degenerated hip by means of total arthroplasty can influence the symptoms of the lumbar spine. ${ }^{9}$ Therefore, the objective of this study is to measure the radiographic spinopelvic parameters and spinopelvic harmony values in patients with low back pain and coxarthrosis indicated for THA and to compare them against the values considered normal for the population.

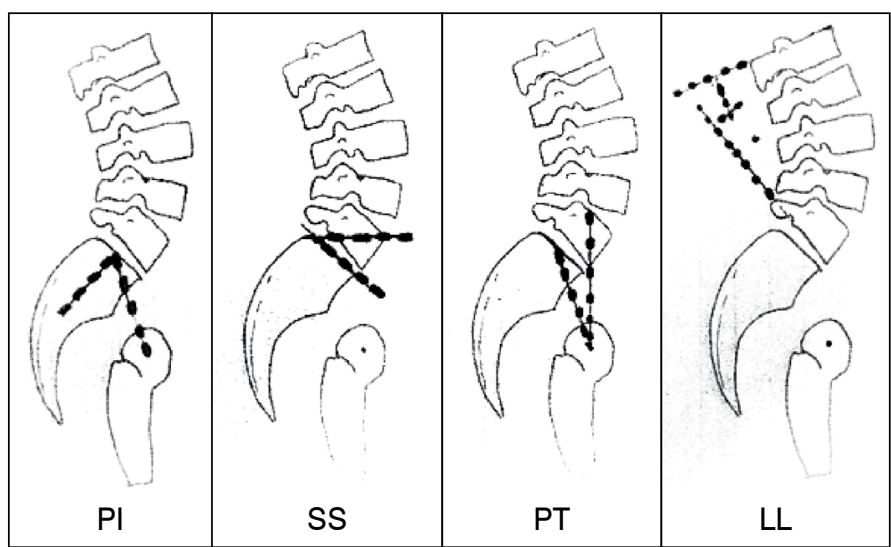

Figure 1. Illustration of the angles of pelvic incidence (PI), sacral slope (SS), pelvic tilt (PT) and lumbar lordosis (LL).

\section{METHODS}

This was a retrospective, observational study approved by the Institutional Review Board of a tertiary university hospital as CAAE number 82941818.2.0000.5225. A waiver of the informed consent form was requested, since this was an observational study without patient intervention in which only their prior radiographic examinations were evaluated.

Patients between the ages of 40 and 100 years, being simultaneously monitored in the outpatient clinic of the Hip Surgery Specialty unit for coxarthrosis with indications of total hip arthroplasty and in the Spine Surgery outpatient clinic for low back pain symptoms, were selected consecutively. The study was conducted from November 2017 to July 2018.

The patients were evaluated on an outpatient basis while awaiting hip arthroplasty surgery. The evaluation was performed by a single orthopedic physician, measuring the sagittal balance angles from radiographs, following the Duval Beaupèrre technique.
Lateral lumbar spine radiographs were taken on a $30 \times 90 \mathrm{~cm}$ chassis, including the heads of the bilateral femurs, with the patient in orthostasis with the knees in extension and the upper limbs in 90-degree flexion. The distance between the radiographic tube and the patient was $230 \mathrm{~cm}$.

The resulting sagittal balance values of the patients with primary unilateral coxarthrosis were compared with the mean angle values of the population considered to be normal according to the literature, as shown in the table below. (Table 1)

In addition to the spinopelvic values, patient epidemiological data such as sex, age, race and body mass index (BMI) were evaluated.

Patients with previous spinal or pelvic surgery, dysmetria of the lower limbs greater than $1 \mathrm{~cm}$, patients with spondylolisthesis, previous spinal or pelvic fracture, scoliosis, Otto pelvis, spinal or pelvic tumors and spondylodiscitis were excluded from the study.

The statistical analysis was conducted using $R$ software, version 3.4.4 and the Student's t-test was applied, with $p<0.05$ considered statistically significant.

Table 1. Showing the values considered normal in the literature.

\begin{tabular}{c|c|c}
\hline Parameters & Range in degrees & Mean in degrees \\
\hline Lumbar lordosis (LL) & $40-60^{\circ}$ & $50^{\circ}$ \\
\hline Sacral slope (SS) & $30-50^{\circ}$ & $39^{\circ}$ \\
\hline Pelvic tilt (PT) & $10-20^{\circ}$ & $12^{\circ}$ \\
\hline Pelvic incidence (PI) & $40-65^{\circ}$ & $51^{\circ}$ \\
\hline Spinopelvic harmony (SH) & $10-20^{\circ}$ & $12^{\circ}$ \\
\hline
\end{tabular}

Source: Henneman S. et al. ${ }^{9}$ and Kulcheski, et al. ${ }^{1}$

\section{RESULTS}

Thirty patients met the study inclusion criteria, 17 of whom were women (56.7\%) and 13 of whom were men (43.3\%). Twenty-three patients $(76.7 \%)$ were White and 7 (23.3\%) were Black. The mean age of the patients was 62.7 years, ranging from 36 to 78 years of age. These data can be better visualized in Table 2 .

The study reported a mean BMl of 25.5, ranging from 17.2 to 37.2 .

Of the thirty patients evaluated, fifteen (50\%) were within the acceptable range for $\mathrm{LL}\left(40-60^{\circ}\right)$ with a mean reference value of $50^{\circ}$, thirteen had LL less than $40^{\circ}(43.3 \%)$ and two patients had $\mathrm{LL}$ greater than $60^{\circ}(6.7 \%)$. Fifty percent (50\%) of the patients had lumbar lordosis greater than $41.75^{\circ}$ (median value).

Another parameter analyzed was SS, with twenty-two patients (73.3\%) within the acceptable range for the reference value, with a mean reference value of $39^{\circ}$. Of the remaining patients, six $(20 \%)$ were below and two (6.7\%) were above the reference value.

As regards $\mathrm{PI}$, of the thirty patients evaluated, sixteen (53.3\%) were within the acceptable values (40-65 ) and fourteen (46.7\%) were above the values considered normal.

In terms of PT, half of the patients were within the acceptable values $\left(10-25^{\circ}\right)$ and the rest were above the acceptable value range.

The mean value observed for the variable $\mathrm{SH}$ was 23.1. The maximum value encountered was 53.9. Twenty of the patients (66.7\%) were classified as imbalanced. (Figure 2)

Figure 3 shows the values observed in our study compared to the literature reference values.

Table 3 shows the distribution of the mean values and standard deviation for each variable analyzed. Figure 4 refers to the values in Table 3.

\section{DISCUSSION}

Comparing the patients presented in this study to the normal population, we observed that our patients are overweight according 
Table 2. Individualized epidemiological data and angle values.

\begin{tabular}{|c|c|c|c|c|c|c|c|c|c|}
\hline Patient & Sex & Age & \begin{tabular}{|c|}
$\begin{array}{c}\text { Lumbar Lordosis } \\
\text { (LL) }\end{array}$ \\
\end{tabular} & Sacral Slope (SS) & $\begin{array}{c}\text { Pelvic Incidence } \\
\text { (PI) }\end{array}$ & Pelvic Tilt (PT) & $\begin{array}{c}\text { Spinopelvic Harmony } \\
\text { (SH = PI - LL) }\end{array}$ & BMI & Race \\
\hline 1 & Man & 56 & 13.2 & 32.7 & 67.1 & 34.4 & $53.9 \mathrm{imbal}$ & 22.8 & W \\
\hline 2 & Man & 59 & 38.6 & 43.3 & 65.8 & 22.5 & $27.2 \mathrm{imbal}$ & 29.4 & $W$ \\
\hline 3 & Woman & 61 & 32 & 20.5 & 44.7 & 24.2 & 12.7 & 18.1 & W \\
\hline 4 & Woman & 64 & 50 & 39 & 77.3 & 38.3 & 27.3 imbal & 27.6 & W \\
\hline 5 & Man & 50 & 62.5 & 43.9 & 81.7 & 37.8 & 19.2 & 25.9 & $W$ \\
\hline 6 & Man & 49 & 25.7 & 26.9 & 43.9 & 17 & $18.2 \mathrm{imbal}$ & 17.2 & W \\
\hline 7 & Man & 54 & 46.8 & 38 & 68.6 & 30.6 & $21.8 \mathrm{imbal}$ & 29.2 & $\mathrm{~B}$ \\
\hline 8 & Woman & 67 & 47 & 30 & 53.9 & 23.9 & $6.9 \mathrm{imbal}$ & 27.4 & W \\
\hline 9 & Man & 71 & 39.4 & 36 & 51 & 15 & $11.6 \mathrm{imbal}$ & 28.6 & $W$ \\
\hline 10 & Woman & 54 & 42.4 & 55 & 71 & 16 & $28.6 \mathrm{imbal}$ & 23 & W \\
\hline 11 & Woman & 63 & 37.3 & 31 & 54 & 23 & 16.7 & 21.2 & $\mathrm{~B}$ \\
\hline 12 & Woman & 57 & 23.8 & 33 & 46 & 13 & $22.2 \mathrm{imbal}$ & 37.2 & $\mathrm{~B}$ \\
\hline 13 & Man & 69 & 45.1 & 36 & 68.7 & 32.7 & $23.6 \mathrm{imbal}$ & 29.1 & $W$ \\
\hline 14 & Woman & 64 & 40 & 46.1 & 70.6 & 24.5 & 30.6 imbal & 27.5 & W \\
\hline 15 & Woman & 70 & 28.7 & 37.5 & 56.5 & 19 & $27.8 \mathrm{imbal}$ & 18.3 & $W$ \\
\hline 16 & Woman & 65 & 42 & 34.3 & 61.5 & 27.2 & 19.5 & 25.6 & $\mathrm{~B}$ \\
\hline 17 & Man & 60 & 36.1 & 29 & 55 & 26 & 18.9 & 26.8 & $W$ \\
\hline 18 & Woman & 58 & 24.5 & 35 & 53.2 & 18.2 & $28.7 \mathrm{imbal}$ & 24.5 & $W$ \\
\hline 19 & Man & 69 & 48 & 40 & 73.5 & 33.5 & $25.5 \mathrm{imbal}$ & 27.3 & $W$ \\
\hline 20 & Woman & 66 & 42.2 & 48.7 & 77.5 & 27.8 & $35.3 \mathrm{imbal}$ & 32.1 & $\mathrm{~B}$ \\
\hline 21 & Woman & 63 & 43 & 29.3 & 54.9 & 25.6 & 11.9 & 24.3 & $W$ \\
\hline 22 & Man & 73 & 41.5 & 39 & 57.7 & 18.7 & 16.2 & 34.5 & $\mathrm{~B}$ \\
\hline 23 & Man & 78 & 30 & 39.5 & 67.9 & 28.4 & $37.9 \mathrm{imbal}$ & 18.4 & W \\
\hline 24 & Woman & 67 & 29 & 27.4 & 48.9 & 21.5 & 19.9 & 23 & $W$ \\
\hline 25 & Woman & 65 & 43.3 & 40.5 & 69.5 & 29 & $26.2 \mathrm{imbal}$ & 33.2 & $\mathrm{~B}$ \\
\hline 26 & Man & 67 & 60.2 & 42.1 & 78.3 & 36.2 & 18.1 & 28.7 & W \\
\hline 27 & Man & 71 & 50 & 34 & 63.4 & 29.4 & $13.4 \mathrm{imbal}$ & 18 & W \\
\hline 28 & Woman & 66 & 47.3 & 55.4 & 86.7 & 31.3 & $39.4 \mathrm{imbal}$ & 22.1 & $W$ \\
\hline 29 & Woman & 69 & 35 & 26 & 49.4 & 23.4 & 14.4 & 26.8 & $W$ \\
\hline 30 & Woman & 36 & 42 & 38.5 & 63.4 & 24.9 & $21.4 \mathrm{imbal}$ & 18.7 & W \\
\hline
\end{tabular}

*imbal - imbalanced, *W-White, *B - Black.

\section{Imbalanced}

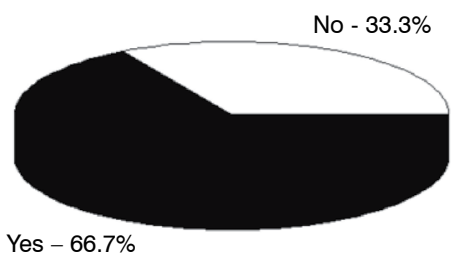

*Black - Imbalanced. White - Balanced.

Figure 2. Representation of the variable $\mathrm{SH}$

to the $\mathrm{WHO}$, with a mean BMI of 25.55. Kulcheski et al. ${ }^{10}$ showed that pelvic tilt is above the mean in the obese population, a fact corroborated in this study. Silva et al. ${ }^{11}$ observed a significant increase in chronic low back pain consistent with an increase in BMI in an adult population. The "extra load" can alter the biomechanical balance of the body and, thus, increase the risk of chronic low back pain in overweight and obese patients. Already associated with coxarthrosis, Mork et al. ${ }^{12}$ conducted a study that analyzed the relationship between the body mass index (BMI) and physical exercises with the risk of osteoarthritis of the knee and hip. In this longitudinal study, they observed more than 15,000 women and 14,000 men in an 11year follow-up in which they analyzed the occurrence of self-reported osteoarthritis. And although they observed a positive association between the BMI and osteoarthritis of the knee, there was no clear association between the BMI and osteoarthritis of the hip.

The mean value observed for the pelvic harmony variable was 23.17 , with a maximum value of 53.9. Our analysis revealed that $66.7 \%$ of the patients were imbalanced. This parameter has been strongly correlated with pain and functional disability, according to Lafage et al. ${ }^{13}$ In the study by Yagi et al., ${ }^{14}$ patients with incompatibility of pelvic harmony $\mathrm{PI}-\mathrm{LL}<10^{\circ}$ presented pelvic retroversion, pelvic obliquity and flexion of the knees, while those with $\mathrm{Pl}-\mathrm{LL}>$ $20^{\circ}$ had thoracolumbar kyphosis and hypolordosis, confirming the worsening of the quality of life.

The acceptable mean LL for a normal population is from $40-60^{\circ}$ In our study, $50 \%$ of the patients were within the normal range, with thirteen patients presenting lumbar lordosis less than $40^{\circ}(43.3 \%)$ and two patients greater than $60^{\circ}(6.7 \%)$. Considering a mean normal lumbar lordosis value of $50^{\circ}$, our study reported a mean value of $39.9^{\circ}$, representing a statistically significant difference when using a p-value $<0.05$. According to Barbosa et al., ${ }^{15}$ lumbar lordosis is influenced by pelvic incidence, pelvic inclination and sacral slope. The increase in pelvic incidence, sacral slope and anterior pelvic inclination (pelvic anteversion) determines the increase in lumbar lordosis. The studies conducted associate the increase in lumbar lordosis with the female sex, black race, orthostatism, increased body mass index (BMI), reduced physical activity and the movement of lumbar spine extension. The reduction in lumbar lordosis is associated with advanced age, the male sex, decreased BMI, increased physical activity and the movement of lumbar spine flexion. In our 


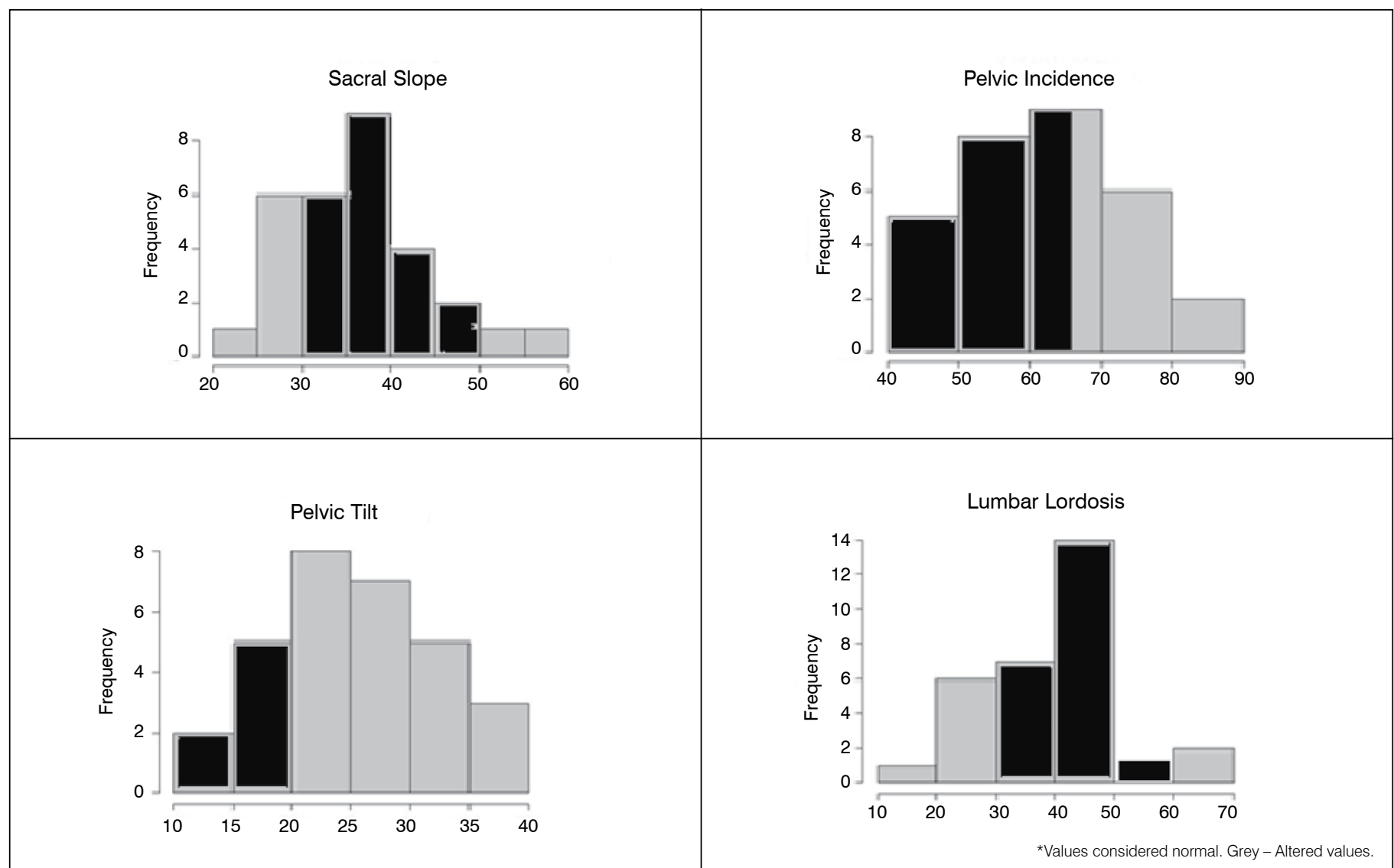

Figure 3. Relationship between the angular variation and the frequency of the variables - SS, PI, LL, and PT.

Table 3. Values observed for variables Age, LL, SS, PI, PT, SH, BMI.

\begin{tabular}{c|c|c|c|c|c}
\hline Variable & Mean & Median & Minimum & Maximum & $\begin{array}{c}\text { Standard } \\
\text { Deviation }\end{array}$ \\
\hline Age & 62.7 & 64.5 & 36 & 78 & 8.47 \\
\hline $\begin{array}{c}\text { Lumbar Lordosis } \\
\text { (LL) }\end{array}$ & 39.55 & 41.75 & 13.2 & 62.5 & 10.63 \\
\hline Sacral Slope (SS) & 36.92 & 36.75 & 20.5 & 55.4 & 8.07 \\
\hline $\begin{array}{c}\text { Pelvic Incidence } \\
\text { (PI) }\end{array}$ & 62.72 & 63.4 & 43.9 & 86.7 & 11.63 \\
\hline Pelvic Tilt (PT) & 25.77 & 25.25 & 13 & 38.3 & 6.79 \\
\hline SH = PI - LL (SH) & 23.17 & 21.6 & 6.9 & 53.9 & 9.77 \\
\hline BMI & 25.55 & 26.35 & 17.2 & 37.2 & 5.19 \\
\hline \multicolumn{7}{c}{} & & & &
\end{tabular}
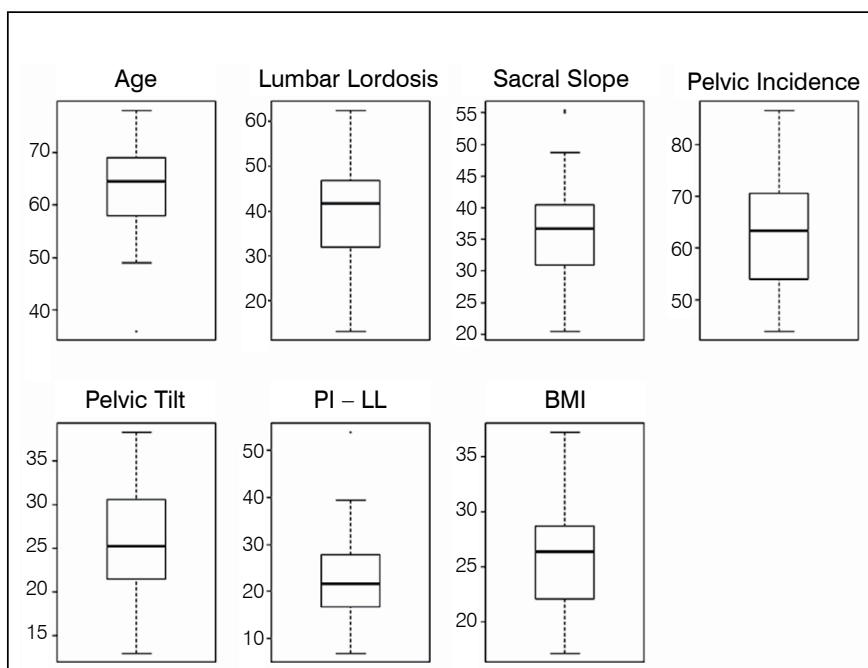

study, we observed a divergence from the study above, where our patients were overweight and hypolordotic.

Regarding sacral slope, six $(20 \%)$ of the thirty patients were below and two (6.7\%) were above the reference value, yielding a $\mathrm{p}$-value of 0.17 . Therefore, it was concluded that the mean sacral slope of the patients in this study $\left(36.92^{\circ}\right)$ does not differ statistically from the mean value of $39^{\circ}$ in the normal population. The more horizontal the sacral plateau, the less the slope. Depending on the position of the sacral plateau, forces may act on the discs and the facet joints causing overload and accelerating disc degeneration.

In our pelvic tilt results, fifteen (50\%) of the patients were above the acceptable values with $p$-value $<0.05$. We concluded that the mean PT of the patients in this study $\left(25.77^{\circ}\right)$ was statistically different from the median value of $15^{\circ}$. Higher values indicated pelvic retroversion. Pelvic retroversion is a compensatory mechanism for sagittal imbalance, shifting the axis of gravity posteriorly. To compensate for the retroversion of the pelvis, there is a cascade of structural changes, an increase in thoracic kyphosis, rectification of lumbar lordosis and flexion of the knees, causing the worsening of the quality of life parameters of these patients and confirming that the pelvic position is correlated with the impairment of their functional capacity.

Regarding PI, we observed that sixteen (53.3\%) of the thirty patients evaluated in this study were within the range of acceptable values $\left(40-65^{\circ}\right)$ and fourteen $(46.7 \%)$ were above the values considered normal, with $p$-value $<0.05$. Therefore, we concluded that the mean pelvic incidence of the study patients (62.72) differs statistically from the mean of $51^{\circ}$ considered to be normal in the literature. Pelvic incidence is an anatomical parameter, exclusive for each individual and does not depend on the orientation of the pelvis. According to Kulcheski et al., ${ }^{10}$ increased pelvic incidence and obesity can lead to early degeneration of the lumbosacral spine and may behave like an intrinsic spinal pathology like spondylolisthesis. In the study by Miranda et al., ${ }^{16}$ patients with high PI had an overload on the posterior elements of the lumbar spine, which increases the 
possibility of the appearance of injuries to the facet joints and the pars interarticulari. However, not all patients with extreme PI values develop pathology of the spine, just as not all patients with some form of pathology necessarily have extreme PI values. A high value implies a very inclined pelvis and accentuated lordosis.

Considering the study by Ben-Galim et al., ${ }^{17}$ according to the 1983 hypothesis of Offierski MacNab, coxarthrosis should be treated first, as it has demonstrated a greater influence on postoperative improvement of a condition of previous low back pain. Grammatopoulos et al. ${ }^{18}$ proposed a study comparing THA before and after lumbar arthrodesis and emphasized that THA should be performed first in a short arthrodesis segment (Up to 2 levels). In their current study, Morimoto et al. ${ }^{19}$ found that HSS associated with an increase in lordosis leads to acetabular subluxation due to contraction of the hip, a condition which induces compensatory anterior inclination of the pelvis to improve the approximation of the acetabulum to the femoral head and they tended to first correct sagittal balance in order to avoid hip revision surgery. We conclude that we must correct sagittal balance before performing THA.

There are few data in the literature that relate HSS to sagittal balance. Further studies with a greater number of patients are needed to improve our understanding of the subject. In this way, we could indicate more accurately the order in the surgical approach to the hip-spine syndrome and thus restore sagittal balance.

\section{CONCLUSION}

We observed a significant difference in the variables $L L, P T, P I$ and $\mathrm{SH}$ between the study patients and the normal population and that approximately $70 \%$ of the patients presented sagittal imbalance when compared to normal sagittal balance values.

All authors declare no potential conflict of interest related to this article.

CONTRIBUTION OF THE AUTHORS: Each author made significant individual contributions to this manuscript. OMMA: Writing, review and performing the surgeries, statistical analysis, intellectual concept and design of the entire research project; XSG: Surgeries, data analysis and writing; ALK, ALS: Statistical analysis, surgeries and review; PGDS: Analysis of the X-rays and review; MLB: Writing, review and intellectual concept.

\section{REFERENCES}

1. Lazennec JY, Brusson A, Rousseau MA. Hip-spine relations and sagital balance clinical consequences. Eur Spine J. 2011;20(Suppl 5):686-98.

2. Offierski C, MacNab I. Hip-spine syndrome. Spine (Phila Pa 1976). 1983;8(3):316-21.

3. World Health Organization (WHO) [internet]. [Accessed in January 15, 2013]. Available from: http://www.who.int/chp/topics/rheumatic/en/

4. Brandt RA, Wajchenberg M. Estenose do canal vertebral cervical e lombar. Einstein. 2008:6(Supl 1):S29-32

5. Vital J, Garcia A, Sauri J, Soderlund C, Gangnet N, Gille O. Equilibrio sagital y su aplicación em patologías de columna vertebral. Rev Ortop Traumatol. 2006:50(6):447-53.

6. Vialle R, Levassor N, Rillardon L, Templier A, Skalli W, Guigui P. Radiographic analysis of the sagittal alignment and balance of the spine in asymptomatic subjects. J Bone Joint Surg Am. 2005:87(2):260-7.

7. Boulay C, Tardieu C, Hecquet J, Benaim C, Mouilleseaux B, Marty C, et al. Sagittal alignment of spine and pelvis regulated by pelvic incidence: standard values and prediction of lordosis. Eur Spine J. 2006;15(4):415-22

8. Vital J, Garcia A, Sauri J, Soderlund C, Gangnet N, Gille O. Equilibrio sagital y su aplicación em patologías de columna vertebral. Rev Ortop Traumatol. 2006;50(6):447-53.

9. Henneman SA, Antoneli PHL, Oliveira GC. Incidência Pélvica: Um parâmetro Fundamental para Definição do Equilíbro Sagital da Coluna Vertebral. Coluna/Columna. 2012;11(3):237-9.

10. Kulcheski AL, Soler IG, Xavier Benato ML, Baretta G. Avaliação angular do equilíbrio sagital em pacientes obesos. Coluna/Columna. 2013;12(3):224-7.

11. Silva MC, Fassa AG, Valle NCJ. Dor lombar crônica em uma população adulta do sul do
Brasil: prevalência e fatores associados. Cad Saúde Pública. 2004·20(2):377-85.

12. Mork PJ, Holtermann A, Nilsen TI. Effect of body mass index and physical exercise on risk of knee and hip osteoarthritis: Iongitudinal data from the Norwegian HUNT study. J Epidemio Community Health. 2012;66(8):678-83

13. Lafage V, Schwab F, Patel A, Hawkinson N, Farcy JP. Pelvic tilt and truncal inclination: two key radiographic parameters in the setting of adults with spinal deformity. Spine (PhilaPa 1976). 2009:34(17):E599-606.

14. Yagi M, Kaneko S, Yato $Y$, Asazuma T. Standing balance and compensatory mechanisms in patients with adult spinal deformity. Spine (Phila Pa 1976). 2016;42(10):E584-91.

15. Barbosa J, Filipe F, Marques E. Hiperlordose Lombar. Revista SPMFR. 2011;20(2):36-42

16. Miranda SF, Corotti VGP, Menegaz P, Ueda W, Vialle EM, Vialle R. Influência da artroplastia total de quadril sobre o equilíbrio sagital lombopélvico: avaliação dos parâmetros radiográficos. Rev Bras Ortop. 2018; in press, corrected proof.

17. Ben-Galim P, Ben-Galimq T. Rand N, Haim A, Hipp J, Dekel S, et al. Hip-spine syndrome: the effect of total hip replacement surgery on low back pain in severe osteoarthritis of the hip Spine (Phila Pa 1976). 2007:32(19):2099-102

18. Grammatopoulos G, Dhaliwal K, Pradhan R, Parker SJ, Lynch K, Marshall R, et al. Does lumbar arthrodesis compromise outcome of total hip arthroplasty? Hip Int. $2019 ; 29(5): 496-503$.

19. Morimoto T, Kitajima M, Tsukamoto M, Yoshihara T, Sonohata M, Mawataril M. Sagittal spino-pelvic alignment in rapidly destructive coxarthrosis. Eur Spine J. 2018;27(2):475-81 